\title{
Empowerment of Women in India: An Overview of Political Participation
}

\author{
Mamoni Das \\ Department of Political Science, J.N.R.M., Port Blair -744101
}

DOI: https://doi.org/10.52403/gijash.20220105

\begin{abstract}
Political participation of women in India is a complex phenomenon being influenced by various factors. Empowerment of women means developing them as more aware individuals, who are politically active, economically productive and independent and are able to make intelligent discussion in matters that affect them. Women turnout during India's 2014 parliamentary general elections was $65.63 \%$, compared to $67.09 \%$ turnout for men. India rank $20^{\text {th }}$ from the bottom in terms of representation of women in parliament. Women have held the posts of president and prime minister in India, as well as chief ministers of various states. Indian voters have elected women to numerous state legislative assemblies and national parliament for many decades. Present article intends to describe and evaluate with the political participation of women in India and discusses about various initiatives taken by the Government of India for empowering women by analyzing position of India in Gender Inequality Index.
\end{abstract}

Keywords: Empowerment, Gender Inequality Participation, Reservation, and Women.

\section{INTRODUCTION}

Empowerment of women involves the improvement of their status in the family, community and society. It ensures women's accessibility to modern development facilities and extends their participation in social, economic and political process and decision making. So, women empowerment is absolutely necessary in India. The constitution of India establishes a parliamentary system of government, and guarantees its citizens the right to be elected, freedom of speech, freedom to assemble and form associations, and vote. The constitution of India attempts to remove gender inequalities by banning discrimination based on sex and class, prohibiting human trafficking and forced labor, and reserving elected positions for women.

The Government of India directed state and local governments to promote equality by class and gender including equal pay and free legal aid, humane working conditions and maternity relief, rights to work and education, and raising the standard of living. Women were substantially involved in the Indian Independence movement in the early $20^{\text {th }}$ Century and advocated for independence from Britain. Independence brought gender equality in the form of constitutional rights, but historically women's political participation has remained low.

\section{Political Empowerment of Women}

Empowerment is a multidimensional social process that helps people gain better control over their own lives. It is a process that fosters power (that is, the capacity to implement) in people, for use in their own lives, their communities, and in their society, by acting on issues that they define as important. Empowerment is multidimensional, social, and a process. It is multi-dimensional in that it occurs within sociological, psychological, economic, and other dimensions. Empowerment also occurs at various levels, such as individual, group, and community. Women's political empowerment is premised on "three 
fundamental and non-negotiable principles: (a) the equality between women and men; (b) Women's right to the full-fledged development of their potentials; and (c) women's right to self representation and self-determination". In empowerment, the key indeed is 'power'.

\section{Political Participation of Women}

Political participation of women in India has been neglected even since independence. Though our country has adopted democratic system of government and the women constitute 48.9 per cent of population of the country, but their political participation is very low. Due to various constraints they could not occupy the positions of power and assume leadership roles. Women's representation in the Lok Sabha has never risen above 8 per cent. The cause of this low level representation does not lie in women's non-participation in politics. Table explains the pattern of electoral participation of women in Lok Sabha in different elections.

Table 1: Pattern of Electoral Participation of Women in Lok Sabha

\begin{tabular}{|c|c|c|c|c|c|c|c|}
\hline Year & $\begin{array}{c}\text { Percentage of } \\
\text { voting men }\end{array}$ & $\begin{array}{c}\text { Percentage of } \\
\text { voting women }\end{array}$ & $\begin{array}{c}\text { Total } \\
\text { seats }\end{array}$ & $\begin{array}{c}\text { Women } \\
\text { seats }\end{array}$ & $\begin{array}{c}\text { Percentage of } \\
\text { women contested }\end{array}$ & $\begin{array}{c}\text { Total } \\
\text { seats }\end{array}$ & $\begin{array}{c}\text { Percentage of } \\
\text { women members }\end{array}$ \\
\hline 1952 & 53.00 & 37.10 & 51 & 23 & 45.09 & 499 & 4.40 \\
\hline 1957 & 56.00 & 38.77 & 70 & 27 & 38.57 & 500 & 5.40 \\
\hline 1962 & 62.10 & 46.63 & 68 & 35 & 51.47 & 503 & 6.70 \\
\hline 1967 & 66.70 & 55.48 & 66 & 31 & 48.43 & 523 & 5.90 \\
\hline 1971 & 69.70 & 49.15 & 86 & 22 & 27.50 & 521 & 4.20 \\
\hline 1977 & 65.62 & 54.96 & 70 & 19 & 25.70 & 544 & 3.40 \\
\hline 1980 & 57.69 & 51.22 & 142 & 28 & 19.70 & 544 & 5.14 \\
\hline 1984 & 63.61 & 68.17 & 421 & 159 & 28.30 & 544 & 7.90 \\
\hline 1989 & 70.79 & 43.90 & 189 & 28 & 14.80 & 525 & 5.30 \\
\hline 1991 & 52.56 & 47.42 & 307 & 33 & 10.75 & 503 & 6.60 \\
\hline
\end{tabular}

Women's participation has been increasing rapidly but it is not satisfactory. They are also denying opportunities to participate in the administration, even in the making of decisions that affect their life and welfare. Though Father of the Nation Mahatma Gandhi had believed that women had a positive role to play in the reconstruction of society and the recognition of their equality was an essential step to bring about social justice. This added to the massive participation by the women in the freedom movement and had a direct impact on the political and social elite, including women. After independence, when the constitution was adopted women like Smt. Sarojini Naidu, Hansa Mehta, Renuka Roy, Durgabai Deshmukh etc. took part in the constitution-making. In our Constitution there is a guarantee of equality and dignity of the individual and it claimed the fundamental rights of women to political and legal equality and guaranteed nondiscrimination in employment and office under the states. Our Constitution had provided many channels for the development and progress of the women.
The preamble of the Constitution, the chapter of Fundamental Rights and Directive Principles of State Policies are among them. The safeguards from atrocities are the specific objectives for this purpose. These constitutional provisions are meant to empower the 48.9 per cent women population in India. But in practice, we find a wide gap between the stated social objectives and achievements, between the legal frame-work and empirical reality, between the symbolism and actuality. And this is the reason that after these constitutional safeguards and legal framework, the participation is still very low.

There are three indicators to assess the political participation of women:

1. Participation in the political process as the voters and candidates in election.

2. Political attitudes such as awareness commitment and involvement in politics and autonomy in political action and behaviour.

3. Their impact on the political process.

Participation in the political process can be judged by the position and number of 
voters and candidates in the election. Election statistics indicate a general trend of increase in the turnout of women voters. In country basis, their percentage increased from 46.6 per cent in 1962 to 55.4 per cent in $1967,49.17$ per cent in 1971 and 52.2 per cent in 1976 and 53.9 per cent in 1981, 54.6 per cent in 1987, 55.2 per cent in 1991, 56.3 per cent in 1997 and there was an increasing trend in other elections also.

\section{Female Participation}

India has a federal form of government, with devolved powers. The electorate votes to elect a national parliament as well as state assemblies. In 2012, India had a minimal percentage of $10.9 \%$ women elected representatives in the national parliament, which is, but relatively higher than Hungary (8.8\%), Brazil $(9.6 \%)$, China $(9.1 \%)$, and Malaysia $(9.8 \%)$.

To remedy low participation of women electors, India in 1994 established quotas (reservations) in constitutional amendments $\left(73^{\text {rd }}\right.$ and $\left.74^{\text {th }}\right)$ to reserve $33 \%$ of seats in local governments for women. The Women's Reservation Bill $\left(108^{\text {th }}\right.$ amendment) has been introduced in the national parliament to reserve $33 \%$ of Lok Sabha and Vidhan Sabha seats for women. The bill has yet to be passed by Lok Sabha and signed into law. The discussion of women's reservations began in the 1920s and continued into the 1930s until a compromise was reached with Britain to allow women in urban areas to vote. Discussion of women's reservations were again introduced in 1974 by the United Nations Commission on the Status of Women in India, but India did not fully establish quotas in local government until 1994. Local governing bodies in India are called Panchayati Raj Institutions (PRI) and one-third of seats and leadership positions must be reserved for women. States such as Andhra Pradesh, Bihar, Chhattisgarh, Jharkhand, Kerala, Maharashtra, Orissa, Rajasthan, Tripura, and Uttarakhand have increased reservations to $50 \%$. The national government has also proposed to raise the level of reservations in PRIs to $50 \%$.Seats reserved for women are rotated for assurance that each seat has an equal chance of being reserved. After the establishment of women's reservations, political participation went from $4-5 \%$ to $25-40 \%$ among women, and gave millions of women the opportunity to serve as leaders in local government.

\section{Political Parties}

India has a multi-party system with the 7 registered parties at the national level. The three largest parties in India are the Indian National Congress (INC), the Bharatiya Janata Party (BJP), and the Communist Party of India (CPI). Political parties have increased outreach among women voters as India's party system has become more competitive. This has included the creation of women's wings in the largest parties. The BJP's wing is the BJP Mahila Morcha, the INC's wing is All India Mahila Congress, and the CPI's wing is the National Federation of India Women.

Women's participation in political parties remained low in the 1990s with 10$12 \%$ membership consisting of women. Indian women have also taken the initiative to form their own political parties, and in 2007, the United Women Front Party was created, and has advocated for increasing the reservation of seats for women in parliament to $50 \%$. Women only govern four of India's political parties. From 1980$1970,4.3 \%$ of candidates and $70 \%$ of electoral races had no women candidates at all. As of 2013, it has been reported of the members of parliament $11 \%$ were women in Lok Sabha and $10.6 \%$ in Rajya Sabha.

\section{Political Activism}

The new wave of feminism in the 1970s was in response to gender inequality issues and stagnant development in India. The committee on the status of Women in India released a report in 1974, and had a significant influence in the reemergence of activism towards gender equality. The report highlighted the significant differences between men and women in India, including the disparity in the sex ratio, mortality rates, 
employment, literacy, and wage discrimination. The report fuelled the women's movement by signifying the ongoing discrimination towards women in India. Gender inequality has remained the focus of the women's movement with specific emphasis on issues such as the Uniform Civil Code, Women's Reservation Bill, and sexual violence against women. Women's organizations both informal and formal have developed at the rural, urban, national, and state levels in India. Women's organizations in India address a variety of issues from the environment, poverty, empowerment, and violence against women.

Indian women are significantly involved at the grass roots level of activism. The Chipko movement that arose in the 1970s is one example of success among the women's movement in India, as women protested the deforestation in Uttarakhand leading to the protection of the region.

\section{Challenges to women's participation}

The level and forms of women's participation in politics is largely shaped by cultural and societal barriers in the form of sexual violence, discrimination and illiteracy.

\section{a. Sexual Violence}

Sexual violence in India is exacerbated by issues of education and marriage. Women are sexually abused. Child marriage, domestic violence and low literacy rates have lowered Indian women's economic opportunities and contributed to sexual violence in India. A 2011 study found, " $24 \%$ of Indian men have committed sexual violence at some point in their lives, $20 \%$ have forced their partners to have sex with them, $38 \%$ of men admitting they had physically abused their partners," Widespread sexual violence is attributed to the fact that violence within marriage is not against the law, and sexual violence goes largely unpunished.

\section{b. Discrimination}

The Constitution of India removed gender inequalities among, caste and gender, but discrimination continues to be a widespread barrier to women's political participation. A 2012 study of 3,000 Indian women found the barriers in participation, specifically in running for political office, in the form of illiteracy, work burdens within the household, and discriminatory attitudes towards women as leaders. Discriminatory attitudes manifest in the limitations presented to Indian women including low access to information and resources. Women rely on receiving information from family or village members, typically men. Women also lack leadership experience due to the fact they are burdened with household duties. The burden of household duties is a significant reason why many Indian women do not participate. Unlike men, there are fewer opportunities for women to get involved in organizations to gain leadership skills. There is little public space for them as men have dominated the political arena for many years in India.

\section{c. Illiteracy}

India is only the largest illiterate populations. In January 2014, the United Nations reported 25.6 percent of all adults in India are illiterate. Literacy among Indian women is $65.46 \%$, which is much lower than literacy among men reported at $82.14 \%$. Illiteracy limits the ability of women to understand the political system and issues. Problems with exploitation, such as women being left off of voters lists, have been reported as illiteracy limits the ability of women to ensure their political rights are exercised. Martial concerning political participation stated, "Because literacy is connected in general with the ability to move outside the home and to stand on one's own outside of it, it is also connected to the ability of women to meet and collaborate with other women."

\section{CONCLUSION}

The attainment in the field of income, employment and in educational front, the scenario of women empowerment seems to be comparatively poor. The need 
of the hour is to identify those loopholes or limitations which are observing the realization of empowerment of women and this initiative must be started from the women folk itself as well as more importantly policy initiative taken by the state and society. Women's empowerment is not a Northern concept women all over the world, including countries in South, have been challenging and changing gender inequalities since the beginning of the history. These struggles have also been supported by many men who have been outraged at injustice against women.

Women represent half the world's population and gender inequality exists in every nation on the planet. Until women are given the same opportunities that men are, entire societies will be destined to perform below their true potentials. The greatest need of the hour is change of social attitude to women. "When women move forward the family moves, the village moves and the nation moves". It is essential as their thought and their value systems lead the development of a good family, good society and ultimately a good nation. The best way of empowerment is perhaps through inducting women in the mainstream of development. Women empowerment will be real and effective only when they are endowed income and property so that they have may stand on their feet and build up their identity in the society. The
Empowerment of Women has become one of the most important concerns of $21^{\text {st }}$ century not only at national level but also at the international level. Government initiatives alone would not be sufficient to achieve this goal. Society must take initiative to create a conducive climate in which there is not gender discrimination and women have full opportunities of self decision making and participating in social, political and economic life of the country with a sense of equality.

Acknowledgement: None

Conflict of Interest: None

Source of Funding: None

\section{REFERENCES}

1. Dr. Minni Thakur, Women Empowerment through Panchayati Raj Institutions.

2. Dr. O.P. Gauba, An Introduction to Political Theory.

3. John J. Harrigan, Politics and Policy in State and Communities.

4. Women's political participation in Indiahttps://en.wikipedia.org/wiki/women\% 27s_political_participation_in_India

How to cite this article: Mamoni Das. Empowerment of women in India: an overview of political participation. Galore International Journal of Applied Sciences \& Humanities. 2022; 6(1): 28-32. DOI: https://doi.org/ 10.52403/gijash.20220105 